Check for updates

Cite this: RSC Adv., 2017, 7, 23727

\title{
A Ruthenium(II) complex as a potential luminescent switch-on probe for G-quadruplex DNA $\uparrow$
}

\author{
Li Li, ${ }^{a}$ Hui-Min Liu, ${ }^{\text {b }}$ Xu-Kui Liu, ${ }^{a}$ Si-Yan Liao, ${ }^{c}$ Yu-Tao Lan, ${ }^{d}$ Qiong Wu, (D) *a \\ Xi-Cheng Wang, ${ }^{* b}$ Qi Wang, ${ }^{a}$ Shuang-Yan Zhang ${ }^{a}$ and Wen-Jie Mei $\mathbb{D}$ *a
}

This study aimed to synthesize two ruthenium(॥) complexes modified with aryl alkynes $\left.[\mathrm{Ru} \text { (phen) })_{2}(\mathrm{TMSEPIP})\right]\left(\mathrm{ClO}_{4}\right)_{2}$ (1, phen = 1,10-phenanthrolin; TMSEPIP $=2$-(2-trimethylsilylethylphenyl) imidazole $[4,5 f][1,10]$ phenanthroline $)$ and $\left[\mathrm{Ru}(\text { phen })_{2}(\mathrm{BEPIP})\right]\left(\mathrm{ClO}_{4}\right)_{2}(2, \mathrm{BEPIP}=2$-(2-phenethylphenyl) imidazole[4,5f][1,10]phenanthroline) and evaluate their ability to act as luminescent probes of c-myc Gquadruplex DNA. It was discovered that the luminescence of 1 decreased in the presence of c-myc Gquadruplex DNA, while the luminescence of 2 clearly increased under the same conditions. Besides, in the presence of double-stranded DNA, the luminescence intensity of 1 and 2 showed little obvious change. It was interesting to find by atomic force microscopy that 1 could promote $c$-myc G-quadruplex DNA self-assembly to form a nano-network structure, while 2 could promote the formation of a nanowire structure. Further studies showed that 1 was inserted into the groove formed by base pairs A6-G8 and G21-T23 of c-myc G-quadruplex DNA, while 2 was inserted into the groove formed by G7G9 and G22-A24. It is speculated that 2 can be developed as a potential luminescent switch-on probe through selectively recognizing and promoting self-assembly of $c$-myc G-quadruplex DNA.

Received 14th February 2017 Accepted 19th April 2017

DOI: $10.1039 / c 7 r a 01853 c$

rsc.li/rsc-advances intermolecular $\pi-\pi$ stacking interactions. ${ }^{7}$ Moreover, polypyridyl $\mathrm{Ru}(\mathrm{II})$ complexes ([Ru(phen $\left.\left.)_{2}(\mathrm{bqbg})\right]^{2+}\right)$ and $\left(\left[\mathrm{Ru}\left\{(\mathrm{bpy})_{2^{-}}\right.\right.\right.$ $\left.\left.\mathrm{Ru}\left(\mathrm{H}_{2} \mathrm{bpib}\right)\right\}_{3}\right] \mathrm{Cl}_{8}$ ) have also facilitated induction of doublestrand DNA condensation into nanoparticles/nanowires. ${ }^{8}$ It has been revealed that condensed nanoparticles of DNA formed using this method can be taken up by cells and used as a oneand two-photon luminescent tracking nonviral gene vector. ${ }^{9}$

Nevertheless, the self-assembly of G-quadruplex DNA promoted by inorganic materials, especially $\mathrm{Ru}(\mathrm{II})$ complexes, still remains uncovered. Accumulated evidence shows that $\mathrm{Ru}(\mathrm{II})$ complexes exhibit excellent binding affinity to Gquadruplex DNA. Chao reported that octahedral polypyridyl $\mathrm{Ru}(\mathrm{II})$ complexes could recognize and bind to telemetric Gquadruplex DNA. ${ }^{10}$ It has also been revealed that arene $\mathrm{Ru}(\mathrm{II})$ complexes can bind and stabilize $c$-myc G-quadruplex in a groove binding mode. ${ }^{11}$ Further studies also showed that nanosized chiral supramolecular complexes preferentially bind to higher-order G-quadruplexes over single G-quadruplex units with $\sim 200$-fold different selectivity, and that dimeric Gquadruplex units can be novel binding sites for large ligands targeting higher-order G-quadruplexes. ${ }^{12}$ Recently, it has been reported that specific $\mathrm{Ru}(\mathrm{II}) \mathrm{dppz}$ compounds can distinguish Gquadruplex from duplex DNA. The photophysical process controlling the DNA-sensing properties has been explored; multiple models have been proposed to explain this "lightswitch" behavior. So, needs to be clarified whether the $\mathrm{Ru}$ (II) complexes can act as a luminescent "switch-on" probe through the high selectivity of G-quadruplex DNA.

\footnotetext{
${ }^{a}$ School of Pharmacy, Guangdong Pharmaceutical University, Guangzhou, 510006 China.E-mail:wenjiemei@126.com; wuqiongniu.1113@163.com

${ }^{b}$ The First Affiliation Hospital, Guangdong Pharmaceutical University, Guangzhou, 510006, China. E-mail: 13902400598@126.com

${ }^{c}$ School of Pharmacy, Guangzhou Medical University, Guangzhou, 510006, China ${ }^{d}$ School of Nursing, Guangdong Pharmaceutical University, Guangzhou, 510006, China

$\dagger$ Electronic supplementary information (ESI) available. See DOI: 10.1039/c7ra01853c
} 


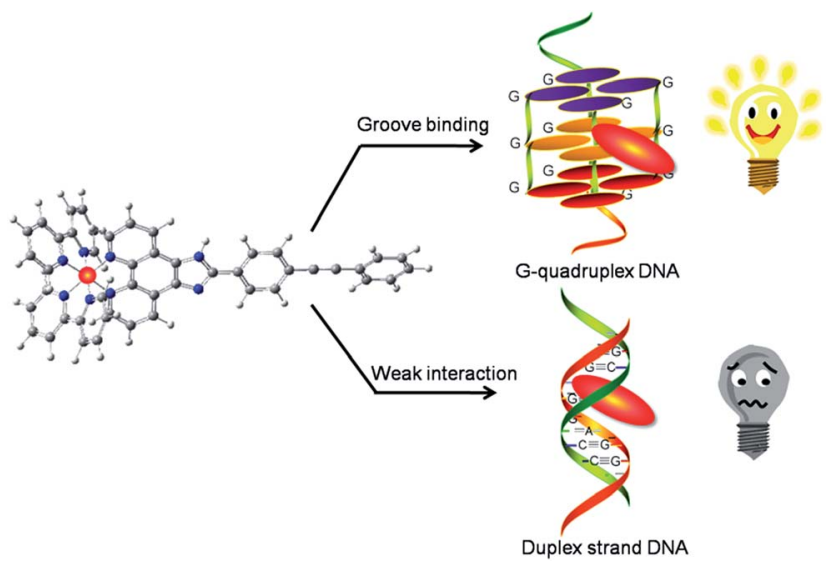

Scheme 1 A ruthenium(॥) complex with phenylethynyl exhibited stronger affinity with G-quadruplex DNA than ds-DNA, which can act as a potential luminescent "switch on" probe for selective recognition of G-quadruplex DNA.

This study reported the preparation of two ruthenium(II) complexes modified by aryl alkyne group using Sonogashira $\mathrm{C}-\mathrm{C}$ coupling reaction under microwave irradiation (see ESI Fig. $\mathrm{S} 1 \dagger$ ), and their interactions with $c$-myc G-quadruplex DNA have also been studied. The results showed that both complexes exhibited stronger affinity to G-quadruplex DNA than to doublestrand DNA. However, they exhibited different binding sites with $c$-myc G-quadruplex DNA in groove binding mode to promote different self-assembled nanostructures. Moreover, the fluorescence emission of 2 enhanced with the addition of $c$ myc G-quadruplex DNA (Scheme 1). Then, a simple, selective, Gquadruplex-based label-free luminescent switch-on assay was investigated.

\section{Experimental section}

\subsection{Materials and methods}

All the chemicals including solvents were obtained from commercial vendors and used as received. Ruthenium(III) chloride hydrate was purchased from Mitsuwa Chemicals. c-myc Gquadruplex DNA (5'-TGGGGAGGGTGGGGAGGG TGGGGAAGG-3') and the fluorescent labeled oligonucleotide, $c$-myc G-quadruplex DNA (5'-FAM-TGGGGAGGGTGGGGAGGGTGGGGAAGG-TAMRA3', FAM: carboxyfluorescein, TAMRA: 6-carboxytetramethylrhodamine) and formed a G-quadruplex conformation by renaturation at $4{ }^{\circ} \mathrm{C}$ for $24 \mathrm{~h}$ after $90{ }^{\circ} \mathrm{C}$ denaturation for $5 \mathrm{~min}$, according to the literature. ${ }^{13,14}$ And $c$-myc, $5^{\prime}$-FAM-c-myc-TAMRA-3' ${ }^{\prime}$ ds26/ss DNA and CT-DNA were purchased from Sangon Biotech (shanghai) Co., Ltd. All aqueous solutions were prepared with doubly distilled water. The Tris- $\mathrm{HCl}$ buffer consisting of Tris (10 mM) and $\mathrm{KCl} / \mathrm{NaCl}(100$ $\mathrm{mM})$, adjust $\mathrm{pH}$ value to $7.2 \mathrm{by} \mathrm{HCl}(0.1 \mathrm{~mol})$, which was applied to UV titrations, fluorescence emission titrations, AFM observation and analytical ultracentrifugation assay. MDA-MB-231 cells were purchased from ATCC, which were cultured by DMEM (HyClone) with $10 \%$ fetal bovine serum (HyClone).

Microwave assisted synthesis was carried out on Anton Paar Monowave 300 microwave reactor. The electronic spectra were recorded on a Shimadzu UV-2550 Spectrophotometer and steadystate emission spectra were recorded on a RF-5301 Fluorescence Spectrophotometer. The ${ }^{1} \mathrm{H}$ NMR, ${ }^{1} \mathrm{H}-{ }^{1} \mathrm{H}$ COSY and ${ }^{13} \mathrm{C}$ NMR spectra were recorded in DMSO- $d^{6}$ solution on a Bruker DRX 2500 spectrometer, and ESI-MS spectra were obtained in methanol on Agilent 1100 ESI-MS system operating at room temperature. The nanostructures were characterized by atomic force microscopy (AFM) (Bruker, Dimension FastScanTM).

\subsection{Synthesis and characterization}

2.2.1 Synthesis of $\left[\mathrm{Ru}(\mathrm{phen})_{2}(p\right.$-TMSEPIP $\left.)\right]\left(\mathrm{ClO}_{4}\right)_{2} \quad$ (1). 1 was synthesized following the literature but with some modifications. In general, $\left[\mathrm{Ru}(\text { phen })_{2}(p\right.$-BrPIP $\left.)\right]\left(\mathrm{ClO}_{4}\right)_{2}(130 \mathrm{mg}, 0.125$ $\mathrm{mmol})$ and trimethylsilylacetylene $(0.09 \mathrm{~mL}, 0.625 \mathrm{mmol})$ was dissolved in dry $\mathrm{CH}_{3} \mathrm{CN}(15.0 \mathrm{~mL})$, and then $\mathrm{Pd}\left(\mathrm{PPh}_{3}\right)_{2} \mathrm{Cl}_{2}$, CuI and dry $\mathrm{Et}_{3} \mathrm{~N}$ were added into the reaction system under $\mathrm{N}_{2}$ atmosphere. The reaction mixture was irradiated by microwaves for $30 \mathrm{~min}$ at $140{ }^{\circ} \mathrm{C}$. After filtrated and dried in vacuums, a dark red powder was obtained. The crude was purified by flash silica gel column chromatography $\left(\mathrm{CH}_{3} \mathrm{CN}\right)$, yields: $30 \%$. ESI-MS (in $\left.\mathrm{CH}_{3} \mathrm{CN}, \mathrm{m} / z\right): 427.4\left(\left[\mathrm{M}-2 \mathrm{ClO}_{4}\right]^{2+}\right), 853.3\left(\left[\mathrm{M}-2 \mathrm{ClO}_{4}-\mathrm{H}\right]^{+}\right) .{ }^{1} \mathrm{H}$ NMR (400 MHz, DMSO- $\left.d^{6}\right) \delta 9.03\left(\mathrm{~d}, J=8.1,2 \mathrm{H}, \mathrm{H}_{\mathrm{c}}\right), 8.79(\mathrm{t}, 2 \mathrm{H}$, $\left.\mathrm{H}_{4^{\prime}}\right), 8.77\left(\mathrm{t}, 2 \mathrm{H}, \mathrm{H}_{4}\right), 8.40\left(\mathrm{~s}, 4 \mathrm{H}, \mathrm{H}_{5,6}\right), 8.37\left(\mathrm{~d}, J=8.4,2 \mathrm{H}, \mathrm{H}_{\mathrm{e}}\right)$, $8.11\left(\mathrm{~m}, 4 \mathrm{H}, \mathrm{H}_{2^{\prime}}, \mathrm{H}_{2}\right), 7.91\left(\mathrm{~d}, J=4.7 \mathrm{~Hz}, 2 \mathrm{H}, \mathrm{H}_{\mathrm{a}}\right), 7.78$ (ddd, $J=$ 8.2, 5.3, $\left.1.8 \mathrm{~Hz}, 4 \mathrm{H}, \mathrm{H}_{3^{\prime}}, \mathrm{H}_{3}\right), 7.73\left(\mathrm{dd}, J=8.3,5.3 \mathrm{~Hz}, 2 \mathrm{H}, \mathrm{H}_{\mathrm{b}}\right.$ ), $7.67\left(\mathrm{~d}, J=8.3 \mathrm{~Hz}, 2 \mathrm{H}, \mathrm{H}_{\mathrm{d}}\right), 1.76\left(\mathrm{~s}, 9 \mathrm{H}, \mathrm{Si}\left(\mathrm{CH}_{3}\right)_{3}\right) .{ }^{13} \mathrm{C} \mathrm{NMR}(101$ MHz, DMSO- $d^{6}$ ) $\delta 171.91$ (s), 153.10 (s), 147.73 (d, $J=9.6 \mathrm{~Hz}$ ), 137.16 (s), 132.67 (s), 130.90 (d, J = 2.8 Hz), 128.50 (s), 126.88 (d, $J=20.1 \mathrm{~Hz}$ ), 40.66 (s), 40.45 (s), 40.24 (s), 40.04 (s), 39.83 (s), $39.62(\mathrm{~s}), 39.41(\mathrm{~s}), 22.97(\mathrm{~s})$.

2.2.2 Synthesis of $\left[\mathrm{Ru}(\text { phen })_{2}(p\right.$-BEPIP $\left.)\right]\left(\mathrm{ClO}_{4}\right)_{2}$ (2). 2 was synthesized as the same methods as above, but with phenylacetylene (0.07 mL, $0.625 \mathrm{mmol})$, yields: 51\%. ESI-MS (in $\left.\mathrm{CH}_{3} \mathrm{CN}, \mathrm{m} / \mathrm{z}\right): 429.5\left(\left[\mathrm{M}-2 \mathrm{ClO}_{4}\right]^{2+}\right), 857.3\left(\left[\mathrm{M}-2 \mathrm{ClO}_{4}-\mathrm{H}\right]^{+}\right) \cdot{ }^{1} \mathrm{H}$ NMR (400 MHz, DMSO- $\left.d^{6}\right) \delta 9.04\left(\mathrm{~d}, J=8.1 \mathrm{~Hz}, 2 \mathrm{H}, \mathrm{H}_{\mathrm{c}}\right), 8.79(\mathrm{t}$, $\left.2 \mathrm{H}, \mathrm{H}_{4^{\prime}}\right), 8.77\left(\mathrm{t}, 2 \mathrm{H}, \mathrm{H}_{4}\right), 8.44\left(\mathrm{~d}, J=8.4,2 \mathrm{H}, \mathrm{H}_{\mathrm{e}}\right), 8.40(\mathrm{~s}, 4 \mathrm{H}$, $\mathrm{H}_{5,6}$ ), 8.12 (ddd, $J=10.2,5.3,1.2 \mathrm{~Hz}, 4 \mathrm{H}, \mathrm{H}_{2^{\prime}}, \mathrm{H}_{2}$ ), 7.88 (d, $J=$ $4.5 \mathrm{~Hz}, 2 \mathrm{H}, \mathrm{H}_{\mathrm{a}}$ ), 7.78 (ddd, $J=8.5,5.3,3.5 \mathrm{~Hz}, 4 \mathrm{H}, \mathrm{H}_{3^{\prime}}, \mathrm{H}_{3}$ ), 7.757.68, (m, $\left.4 \mathrm{H}, \mathrm{H}_{\mathrm{b}}, \mathrm{H}_{\mathrm{d}}\right), 7.61-7.57\left(\mathrm{~m}, 2 \mathrm{H}, \mathrm{H}_{\mathrm{g}}\right), 7.46(\mathrm{~d}, J=2.1 \mathrm{~Hz}$, $1 \mathrm{H}, \mathrm{H}_{\mathrm{h}}$ ), 7.45 (d, $\left.J=1.9 \mathrm{~Hz}, 2 \mathrm{H}, \mathrm{H}_{\mathrm{f}}\right) .{ }^{13} \mathrm{C}$ NMR (101 MHz, DMSO$\left.d^{6}\right) \delta 153.08(\mathrm{~s}), 147.76(\mathrm{~d}, J=10.0 \mathrm{~Hz}), 137.12(\mathrm{~s}), 132.24(\mathrm{~s})$, 131.84 (s), 130.88 (s), 129.29 (s), 128.53 (s), 127.04 (s), 126.78 (s), $125.91(\mathrm{~s}), 40.59$ (d, $J=15.5 \mathrm{~Hz}), 40.37$ (d, $J=17.9 \mathrm{~Hz}), 40.16$ (d, $J$ $=18.2 \mathrm{~Hz}), 40.04(\mathrm{~s}), 39.75(\mathrm{~d}, J=16.5 \mathrm{~Hz}), 39.53(\mathrm{~d}, J=18.3 \mathrm{~Hz})$, 39.41 (s), 22.97 (s).

\subsection{Fluorescence properties assay}

The fluorescence quantum yields $\Phi$ (relative values) of samples were calculated according to the following expression: ${ }^{15}$

$$
\Phi_{\text {unk }}=\Phi_{\text {std }}\left(\frac{I_{\text {unk }}}{A_{\text {unk }}}\right)\left(\frac{A_{\text {std }}}{I_{\text {std }}}\right)\left(\frac{\eta_{\text {unk }}}{\eta_{\text {std }}}\right)^{2}
$$

where the subscripts unk and std respectively refer to the sample and the reference, $\Phi_{\text {unk }}$ and $\Phi_{\text {std }}$ are the fluorescence quantum yields of the sample and standard, respectively. $I_{\mathrm{unk}}$ and $I_{\text {std }}$ are the integrated emission intensities of the sample 
and standard, respectively. $A_{\text {unk }}$ and $A_{\text {std }}$ are the absorbances of the sample and standard at the best excitation wavelengths of sample, respectively, and $\eta_{\mathrm{unk}}$ and $\eta_{\text {std }}$ are the indexes of refraction of the sample and standard solutions. The fluorescence quantum yields of two complexes were measured at best excitation wavelengths using $\mathrm{Ru}(\mathrm{bpy})_{3}{ }^{2+}$ in $\mathrm{CH}_{3} \mathrm{CN}$ as the radiative quantum yield standard. Fluorescence spectroscopy measurements were performed using a $1 \mathrm{~cm}$ path length quartz cell. Luminescence titrations of $\mathrm{Ru}$ (II) complexes were measured by using fixed ruthenium concentration $(4 \mu \mathrm{M})$ with increasing c-myc G4 DNA or CT-DNA. The first spectrum was taken after 5 min to allow the sample $(3 \mathrm{~mL})$ to equilibrate. Then, $2 \mu \mathrm{L}$ of a $100 \mu \mathrm{M}$ DNA solution was added to the sample cell with thorough mixing. The titration processes were repeated until there was no apparent.

\subsection{Atom force microscopy observation}

The mixed solution of DNA $(100 \mu \mathrm{M})$ and Ru(II) complexes (100 $\mu \mathrm{M})$ were incubated for three days. Then, the mixed solution of $10 \mathrm{uL}$ was removed to a mica plate and naturally volatilized for $2 \mathrm{~h}$. An image of the sample was captured by atomic force microscopy (AFM).

\subsection{Analytical ultracentrifugation assay}

Analytical ultracentrifugation was operated by ProteomeLab XLA/XL-I (Beckman Coulter). Sedimentation velocity experiments were carried out in a Beckman XL-I analytical ultracentrifuge. Samples were prepared with a final concentration of $100 \mu \mathrm{M} c$ myc G-quadruplex DNA, c-myc G-quadruplex DNA $(100 \mu \mathrm{M})$ bound 1 and $2(100 \mu \mathrm{M})$ in buffer (Tris-HCl buffer $\mathrm{pH} 7.2$, $10 \mathrm{mM}$ Tris and $100 \mathrm{mM} \mathrm{KCl}$ ). $c$-myc G-quadruplex DNA and 1 or 2 were mixed $1: 1$ with a final volume of $400 \mu \mathrm{L}$. Samples were loaded into a two-channel ultracentrifuge cell, and a blank buffer consisting of the system storage buffers, Tris-HCl buffer was loaded into the blank channel. For interference experiments, sapphire windows were used, and for absorbance experiments, quartz windows were used. Cells were loaded in an An-60Ti rotor and centrifuged at $50000 \mathrm{rpm}$ at $20{ }^{\circ} \mathrm{C}$. Data were analyzed using SEDFIT using a continuous $\mathrm{c}(\mathrm{s})$ with bimodal $f$ / $f_{0}{ }^{16}$ Fits were considered satisfactory if the root mean square deviation was less than 0.009 and the residuals were randomly distributed.

\subsection{Molecular docking}

Automated docking studies were performed with three different docking algorithms, which were: (1) AutoDock 3.0 ('Lamarckian' genetic algorithm); (2) FlexX 1.10 (incremental construction algorithm, as implemented in Sybyl 6.8), and (3) GOLD 1.2 (i.e., the "Darwinian" genetic algorithm). As scoring is a very important second aspect of automated docking methodologies, it was decided to investigate the effect of rescoring this is a process of reprioritization of the docking solutions (i.e., primarily ranked by the "native" scoring function implemented in the docking program) with an additional stand-alone scoring function.

\subsection{Spectroscopy analysis}

The recording of electronic absorption spectra was carried out at room temperature to determine the binding affinity between $c$-myc G4-DNA/CT-DNA and ruthenium(II) complexes([c-myc G4DNA $]=100 \mu \mathrm{M}$ [CT-DNA] $=6 \mathrm{mM}) .3 .0 \mathrm{~mL}$ solutions of the blank buffer and the ruthenium complex samples $(10 \mu \mathrm{M})$ were placed in the reference and sample cuvettes respectively, following which, the first spectrum was recorded in the wavelength range of 200-800 $\mathrm{nm}$. During the titration, an aliquot (2 $\mu \mathrm{L}$ ) of buffered DNA solution was added to each cuvette to eliminate the absorbance of $c$-myc DNA/CT-DNA itself, and the solutions were mixed by repeated inversions. After the solutions were mixed for approximately five minutes, the absorption spectra were recorded. The titration process was repeated until there was no change in the spectra for at least four titrations, which indicated that binding saturation had been achieved.

\subsection{Melting and competitive FRET assays}

The fluorescent labeled oligonucleotide, $c$-myc G-quadruplex DNA (5'-FAM-TGGGGAGGGTGGGGAGGG TGGGGAAGGTAMRA-3', FAM: carboxyfluorescein, TAMRA: 6-carboxy tetramethylrhodamine) used as the FRET probe was diluted in Tris$\mathrm{HCl}$ buffer and then annealed by being heated to $90{ }^{\circ} \mathrm{C}$ for $5 \mathrm{~min}$, followed by slowly cooling to room temperature. ${ }^{17}$ Ds26 duplex DNA (CAATCGGATCGAATTCGATCCGATTG) and singlestranded (ss) DNA f( $5^{\prime}$-CTCAT4C2ATACAT2A3GATAGTCAT-3 $\left.{ }^{\prime}\right)$ were competitive binders to evaluate the selective binding ability of $\mathrm{Ru}(\mathrm{II})$ complexes with $c$-myc G4 DNA. Fluorescence melting curves were determined with a Bio-RadiQ5 realtime PCR detection system, by using a total reaction volume of 25 $\mathrm{mL}$, with labeled oligonucleotide $(1 \mu \mathrm{M})$ and different concentrations of complexes in Tris-HCl buffer. ${ }^{18}$ A constant temperature was maintained for $30 \mathrm{~s}$ prior to each reading to ensure a stable value. Final analysis of the data was carried out by using Origin7.5 (Origin Lab Corp.).

\subsection{Western blot analysis}

Total cellular proteins were extracted by incubating cells in lysis buffer obtained from Cell signaling Technology and protein concentrations were determined by BCA assay. SDS-PAGE was done in $10 \%$ tricine gels loading equal amount of proteins per lane. After electrophoresis, separated proteins were transferred to nitrocellulose membrane and blocked with 5\% non-fat milk in TBST buffer for $1 \mathrm{~h}$. After then, the membranes were incubated with primary antibodies at 1 : 1000 dilutions in 5\% nonfat milk overnight at $4{ }^{\circ} \mathrm{C}$, and then secondary antibodies conjugated with horseradish peroxidase at $1: 2000$ dilution for $1 \mathrm{~h}$ at room temperature. Protein bands were visualized on X-ray film using an enhanced chemiluminescence system (Kodak).

\section{Results and discussion}

\subsection{The chemical properties of ruthenium(II) complexes}

Excitation of $1(4 \mu \mathrm{M})$ at about $462 \mathrm{~nm}$ in Tris-HCl-KCl buffer resulted in an emission with $\lambda_{\max }$ at $583 \mathrm{~nm}$, while the excitation of $2(4 \mu \mathrm{M})$ at about $467 \mathrm{~nm}$ led to the emission with $\lambda_{\max }$ at 
A

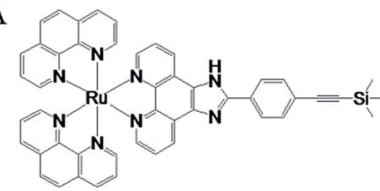

$\mathrm{C}$

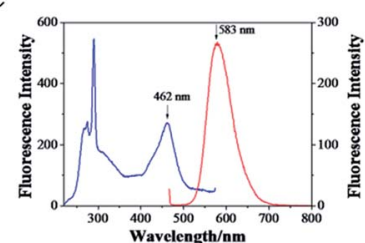

$\mathrm{B}$

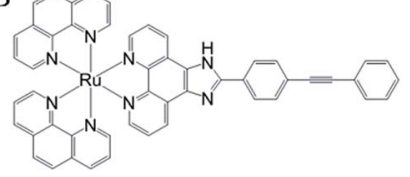

$\mathrm{D}$

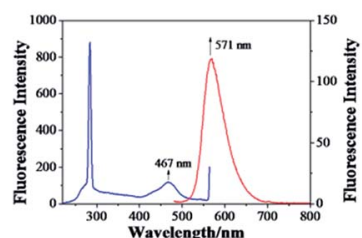

Fig. 1 The synthetic ruthenium(॥) complexes with phenylethynyl 1 (A) and 2 (B). The fluorescence properties of 1 (C) and 2 (D). [Ru] $=4 \mu \mathrm{M}$, excitation spectra (blue) and emission spectra (red).

$571 \mathrm{~nm}$. The Stokes shift was determined from the excitation and emission spectral peak energies, the noticeable differences between the excitation and emission wavelengths was calculated to be almost $121 \mathrm{~nm}$ of 1 and $104 \mathrm{~nm}$ of $2,{ }^{19}$ (Fig. 1) which might contributed to the presence of trimethylsilylacetylene exhibited better electron-donating conjugation effect than phenylethynyl. ${ }^{20,21}$ The quantum yields of $\mathbf{1}$ and 2 in $\mathrm{CH}_{3} \mathrm{CN}$ were 0.028 and 0.016 , respectively. Interestingly, it was found that, with the addition of $c$-myc G-quadruplex DNA, the fluorescence intensity of 1 decreased gradually, about 35.6\%, which may be attributed to the binding of $\mathbf{1}$ to $c$-myc G-quadruplex DNA (Fig. 2A). However, for 2, the fluorescence intensity increased dramatically, about $81.6 \%$, which may be attributed to switch-on assay (Fig. 2B). ${ }^{22}$ Moreover, strong red fluorescence of $\mathbf{1}(4 \mu \mathrm{M})$ in Tris-HCl-KCl buffer solution was observed. When excited at $365 \mathrm{~nm}$ of ultraviolet (UV) light, with the addition of $c$ $m y c$ DNA, the fluorescence emission decreased (Fig. 2E); but for 2, the fluorescence emission increased (Fig. 2F). However, with the addition of CT-DNA, the fluorescence intensity of $\mathbf{1}$ and $\mathbf{2}$

were both decreased slightly (Fig. 2C and D), and the fluorescence emission of $\mathbf{1}$ and $\mathbf{2}$ have little obvious change (Fig. 2G and $\mathrm{H}$ ), which indicated that both ruthenium(II) complexes exhibited weak interactions with duplex strand DNA. Above results suggested that the binding of 2 to $c$-myc G-quadruplex DNA might act as a switch-on luminescent probe to recognize $c$-myc G-quadruplex DNA. ${ }^{23-25}$

\subsection{High-order self-assembly of G-quadruplex DNA controlled by ruthenium(II) complexes}

The self-assembly of $c$-myc G-quadruplex DNA induced by both $\mathrm{Ru}$ (II) complexes was first confirmed by AFM. Incubation of 1 with $c$-myc G-quadruplex DNA led to the formation of a mesh hole-net structure with diameters of approximately 500$1000 \mathrm{~nm}$ (Fig. 3A), ${ }^{7,26}$ which indicated that $c$-myc G-quadruplex DNA self-assembled into an orderly DNA nano-network structure in the presence of 1. As for $c-m y c$ G-quadruplex DNA incubated with 2, a typical pipeline-like structure of approximately $200 \mathrm{~nm}$ was observed under AFM (Fig. 3B), indicating that a nanowire structure was formed from the self-assembly of $c$-myc G-quadruplex DNA promoted by $2 .^{27}$ Moreover, when amplified, some hole-net structures with an average size of about $250 \mathrm{~nm}$ were observed in the nanowires of DNA, indicating that a mixed self-assembled G-quadruplex DNA formed nano-network and nanowire structures (Fig. 3B). ${ }^{28}$ The aforementioned results indicated that both complexes could promote DNA self-assembly but form different nanostructures, which might be attributed to different binding abilities.

\subsection{Molecular conformation of G-quadruplex DNA induced by ruthenium(II) complexes in solution}

The oligomeric state of $c$-myc G-quadruplex DNA in solution was investigated in the presence and absence of $\mathbf{1}$ and 2 by sedimentation velocity analytical ultracentrifugation. The effects of $\mathbf{1}$ and $\mathbf{2}$ were further examined as a function molecular size on

\section{A}

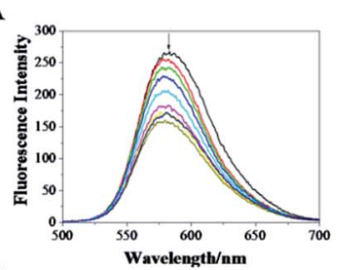

E

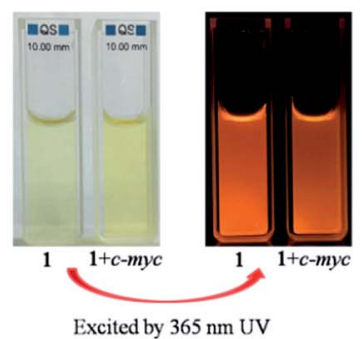

B

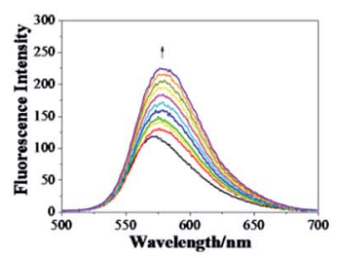

F

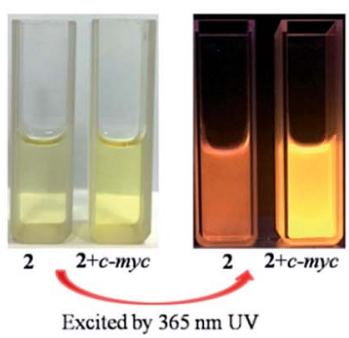

$\mathrm{C}$

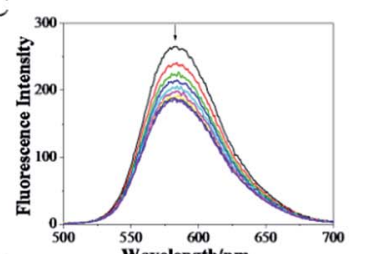

G

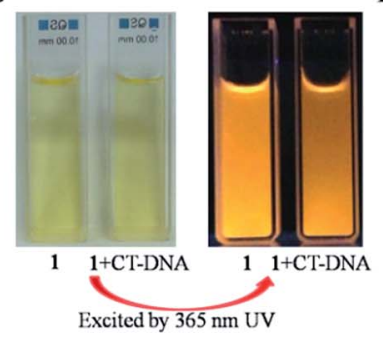

$\mathrm{D}$

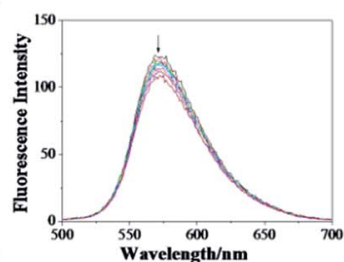

$\mathrm{H}$

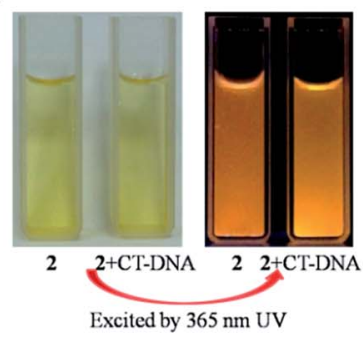

Fig. 2 The changes of fluorescence intension of 1 (A) and 2 (B) with the addition of $c$-myc G-quadruplex DNA, 1 (C) and 2 (D) with the addition of CT-DNA. ([Ru] $=4 \mu \mathrm{M},[c-m y c]=0.067 n \mu \mathrm{M}, n=0,1,2 \ldots)$; the fluorescence emission of $1(\mathrm{E})$ and $2(\mathrm{~F})$ in the absence and presence of $c-m y c \mathrm{G} 4$ DNA in a Tris- $\mathrm{HCl}-\mathrm{KCl}$ buffer solution ( $\mathrm{pH} 7.2), 1(\mathrm{G})$ and $2(\mathrm{H})$ in the absence and presence of CT-DNA in Tris- $\mathrm{HCl}-\mathrm{NaCl}$ buffer solution (pH 7.2), which excited at $365 \mathrm{~nm}$ using a portable UV lamp, ([Ru] $=20 \mu \mathrm{M}$, [c-myc] $=20 \mu \mathrm{M},[\mathrm{CT}-\mathrm{DNA}]=20 \mu \mathrm{M})$. 
A
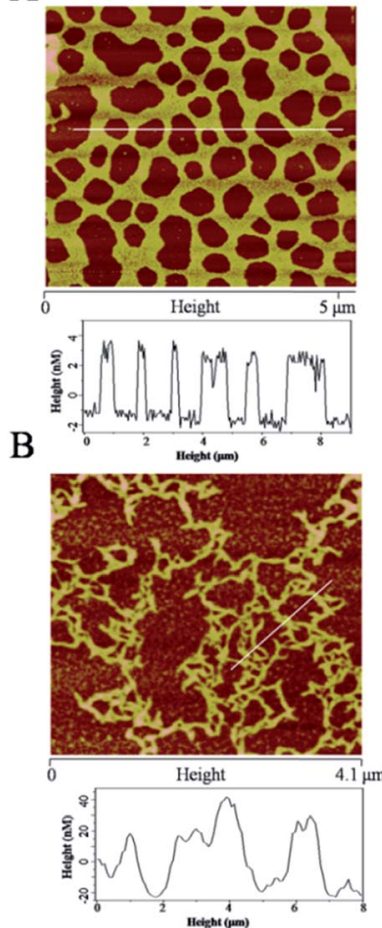
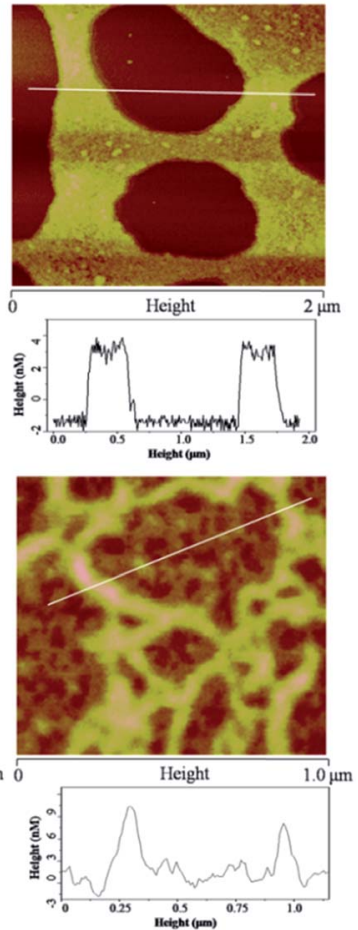

Fig. 3 (A) Atomic force microscopic (AFM) image and analysis of c-myc DNA self-assembled into nano-network structures in the presence of 1 . (B) AFM image and analysis of $c-m y c$ DNA self-assembled into nanowire structures in the presence of 2 . [Ru]:[c-myc] $=1: 1,(100 \mu \mathrm{M})$.

the ability to visually detect molecular conformation change of $c$-myc G-quadruplex DNA. Under higher loading concentration $(100 \mu \mathrm{M})$ of free $c-m y c$ G-quadruplex DNA, the weight average $\mathrm{s}$

value shifted slightly to $1.854 \mathrm{~S}$ and $3.378 \mathrm{~S}$, and the relative amount of monomer reached to $79.8 \%$ and trimer for $18.9 \%$ of absorption at the expense of the other species. This was illustrated in Fig. 4d, which suggested that free c-myc G-quadruplex DNA in solution displayed two possible state having the following molecular weights, monomer state of $10.6 \mathrm{kDa}$, trimer state of $26.1 \mathrm{kDa}$. Then, upon the addition of $\mathbf{1}$, the $c-m y c \mathrm{G}-$ quadruplex DNA in solution displayed a good deal of aggregation state with higher than monomer (Fig. 4e), $19.5 \mathrm{kDa}$ and $2.410 \mathrm{~S}$ (dimer, 95.091\%), $221 \mathrm{kDa}$ and $12.18 \mathrm{~S}$ (polymer, $0.132 \%) .{ }^{29,30}$ However, in the presence of 2 , the sedimentation distributions changed drastically, and $72.13 \%$ of the absorbance corresponded to a trimeric species, while the remaining absorbance sedimented as a heterogeneous mixture with $\mathrm{s}$ values ranging between 2.09 and $21.4 \mathrm{~S}$, corresponding to highly anisotropic aggregates ranging between 14.5 and 468 $\mathrm{kDa}$ in size. It showed that with the increasing of 2 , the $c$-myc Gquadruplex DNA displayed plenty of trimerization state and different aggregation state (Fig. 4f), $29.5 \mathrm{kDa}, 2.09 \mathrm{~S}$ (trimer), $77.4 \mathrm{kDa}, 6.38 \mathrm{~S}$ (polymer) and $139 \mathrm{kDa}, 9.41 \mathrm{~S}$ (polymer). In any case, the sedimentation velocity further revealed that 2 do participate in the association to promote the self-assembly of $c$ myc G-quadruplex DNA to form nanowire.

\subsection{Self-assembly orientations of ruthenium(II) complexes with $c$-myc G-quadruplex DNA}

To further understand the self-assembly of $c$-myc G-quadruplex DNA enhanced by these Ru(II) complexes, the molecular docking simulations were carried out to confirm the binding Gquadruplex DNA in a typical groove binding mode. Moreover, 1 was inserted into the groove of $c$-myc G-quadruplex DNA,

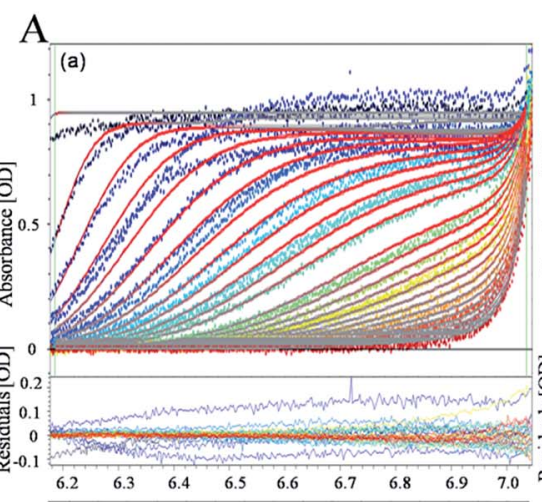

$\mathrm{B}$
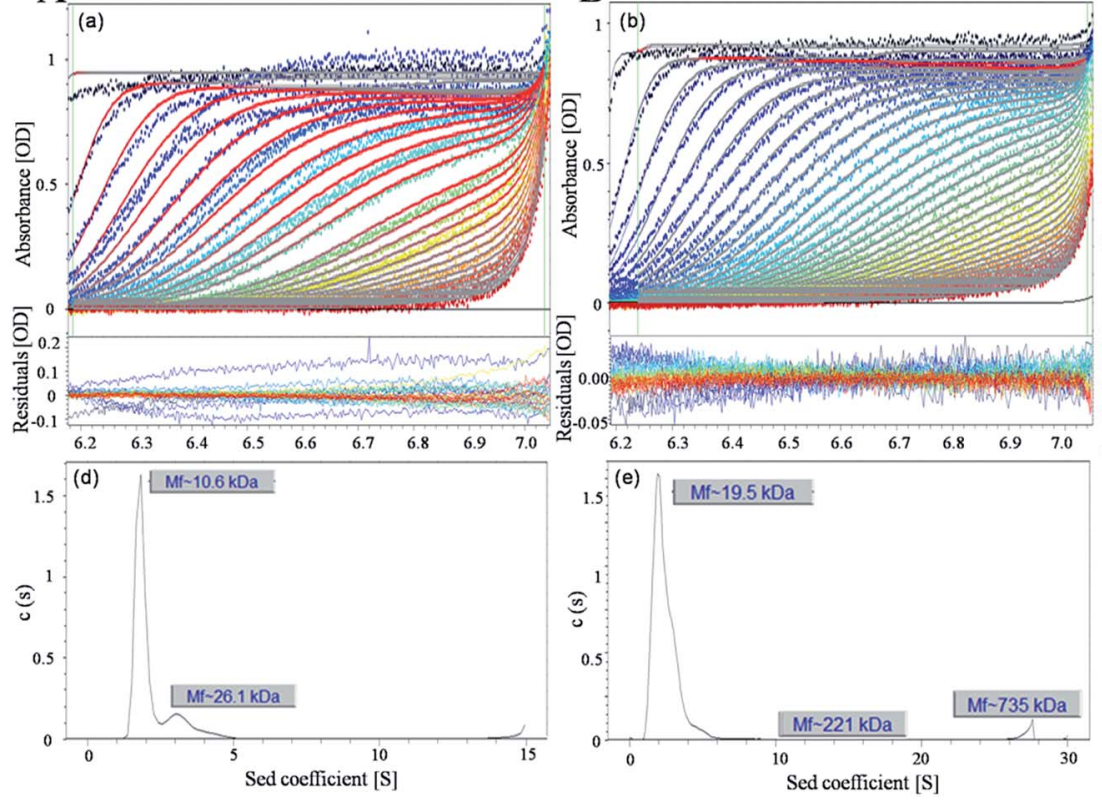

$\mathrm{C}$
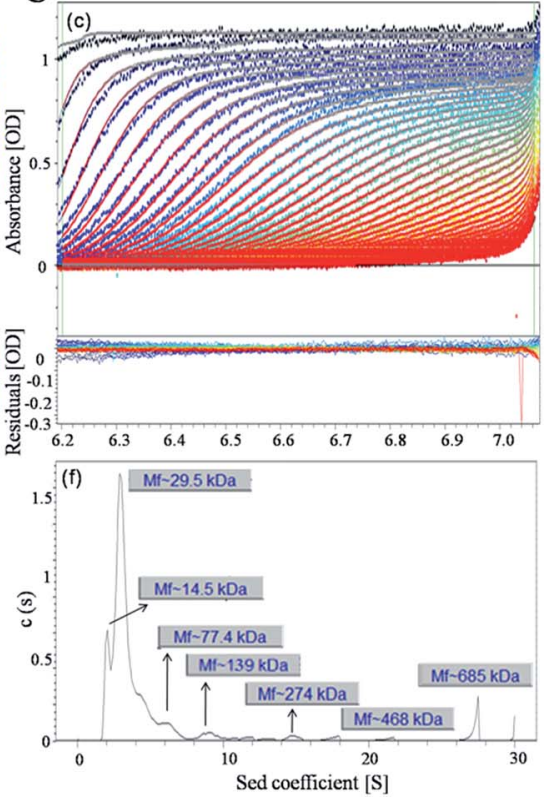

Fig. 4 Analytical ultracentrifugation analyzed the sedimentation velocity (SV) of c-myc (A), 1 (B) and 2 (C). All theoretically calculated SV concentration profiles, $s(r, t)$, were generated using SEDFIT, fitting error and fitting curve $(a-c)$. Sedimentation coefficient distributions $c(s)$ from the analysis of the sedimentation profiles of the simulated c-myc G-quadruplex-1/2-bound DNA system ( $d$ - $f$ ), SV runs monitored by absorbance at $300 \mathrm{~nm}$. Concentrations are $[c-m y c]=100 \mu \mathrm{M},[1]=100 \mu \mathrm{M}$ and [2] $=100 \mu \mathrm{M}$. 


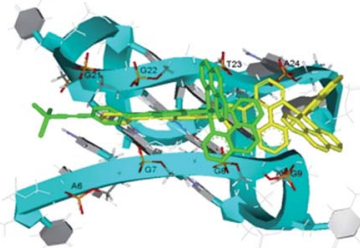

A

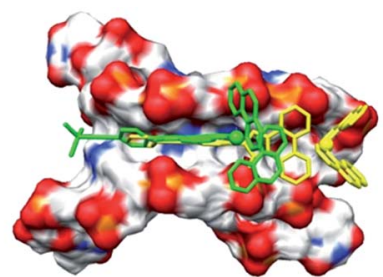

B
Fig. 5 The binding sites (A) and binding mode (B) of 1 and 2 with $c$ myc G4 DNA calculated by molecular docking.

which was formed by base pairs A6-G8 and G21-T23 with a binding energy of $-6.29 \mathrm{kcal} \mathrm{mol}^{-1}$. However, 2 was found to insert into the groove of $c-m y c$ G-quadruplex DNA, which was $c$ myc G-quadruplex DNA led to enhanced fluorescence, formed by base pairs G7-G9 and G22-A24 with a binding energy of -7.83 kcal mol ${ }^{-1}$ (Fig. 5). ${ }^{11}$ As for 1 , the presence of trimethylsilylacetylene provided steric hindrance, and the molecules were inserted into a shallow groove of G-quadruplex DNA. However, for 2 , the presence of phenylethynyl provided better planarity, and the molecules were inserted into a deep groove of Gquadruplex DNA through $\pi-\pi$ stacking. These data indicated that both $\mathrm{Ru}(\mathrm{II})$ complexes might bind to $c$-myc G-quadruplex DNA in a groove binding mode, and 2 exhibited stronger binding ability than $1 .^{12}$ Moreover, different binding sites guide different self-assembly nanostructures of $c$-myc G-quadruplex DNA.

\subsection{G4/ds DNA-binding properties}

Electronic spectra is one of the most common methods to investigate the interactions of small molecules with biological macromolecules. As shown in Fig. 6A, the electronic spectra of 1 exhibited the characteristic intraligand (IL) charge transfer absorption in the range of $250-300 \mathrm{~nm}$ with a maximum at $263 \mathrm{~nm}$, upon the addition of $c$-myc G4-DNA, the hypochromism value was $42.3 \%$. For 2 , the hypochromism value was $45.0 \%$ (Fig. 6B). However, further analysis upon the addition of CTDNA showed that both ruthenium(II) complexes bind to CTDNA in weak affinity (Fig. 6C and D). These data demonstrated that both complexes displayed higher affinity with the $c$ myc G4 DNA than that of CT-DNA; especially 2, exhibited stronger affinity to $c-m y c$ G4-DNA. ${ }^{31,32}$

\subsection{Selective recognition of G-quadruplex DNA}

To further confirm the selectivity of Ru(II) complexes with c-myc G4 DNA, FRET melting assay was carried out to investigate the melting changes of $\mathbf{1}$ and 2 to c-myc G-quadruplex DNA. As shown in Fig. 7, the melting point of $c-m y c$ G4 DNA was about $41.2{ }^{\circ} \mathrm{C}$, while upon the addition of $6.0 \mu \mathrm{M}$ of 1 and 2 , the melting point of $c-m y c$ G4 DNA (the $\left.T_{\mathrm{m}}\right)$ increased $46.9\left(\Delta T_{\mathrm{m}}=\right.$ 5.7) and $55.9\left(\Delta T_{\mathrm{m}}=14.7\right)^{\circ} \mathrm{C}$, respectively. These data indicated that both complexes can stabilize the c-myc G4 DNA, especially 2, displayed better stability than $\mathbf{1}$, which accord with aforementioned results. Furthermore, the competitive FRET assay
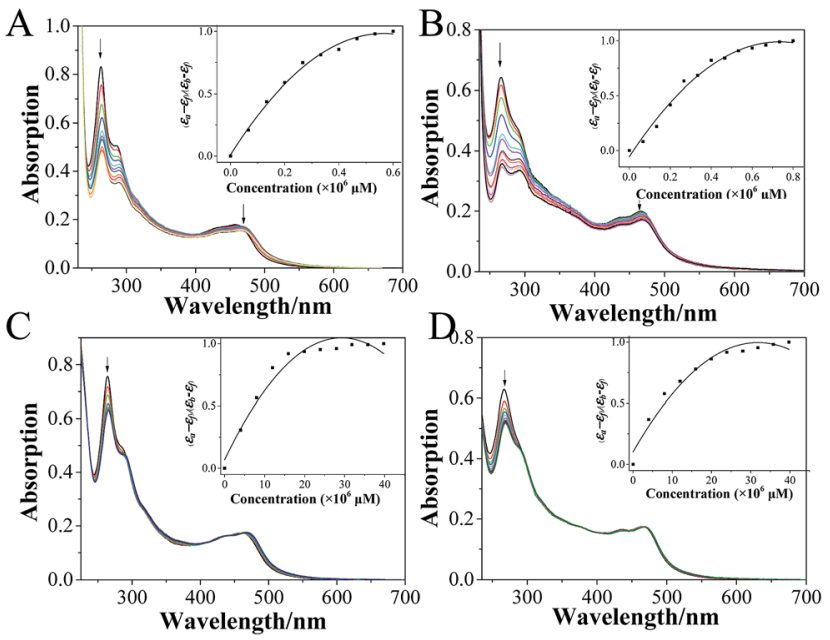

Fig. 6 The study of the interactions between 1 and 2 with c-myc G4 DNA/CT-DNA using spectroscopic method. The electronic spectras of $1(\mathrm{~A})$ and 2 (B) in the absence and presence of c-myc G4 DNA in the Tris- $\mathrm{HCl}-\mathrm{KCl}$ buffer solution (pH 7.2), 1 (C) and 2 (D) in the absence and presence of CT-DNA in the Tris- $\mathrm{HCl}-\mathrm{NaCl}$ buffer solution $(\mathrm{pH} 7.2),[\mathrm{Ru}]=10 \mu \mathrm{M},[c-m y c \mathrm{G} 4 \mathrm{DNA}]=0-0.66 \mu \mathrm{M},[\mathrm{CT}-\mathrm{DNA}]=$ $0-60 \mu \mathrm{M}$.

was also performed to confirm the selectivity of both $\mathrm{Ru}(\mathrm{II})$ complexes between c-myc G-quadruplex DNA and single or duplex strand DNA. According to the results of FRET competitive experiments, the melting point for $c-m y c$ G4 DNA undergo
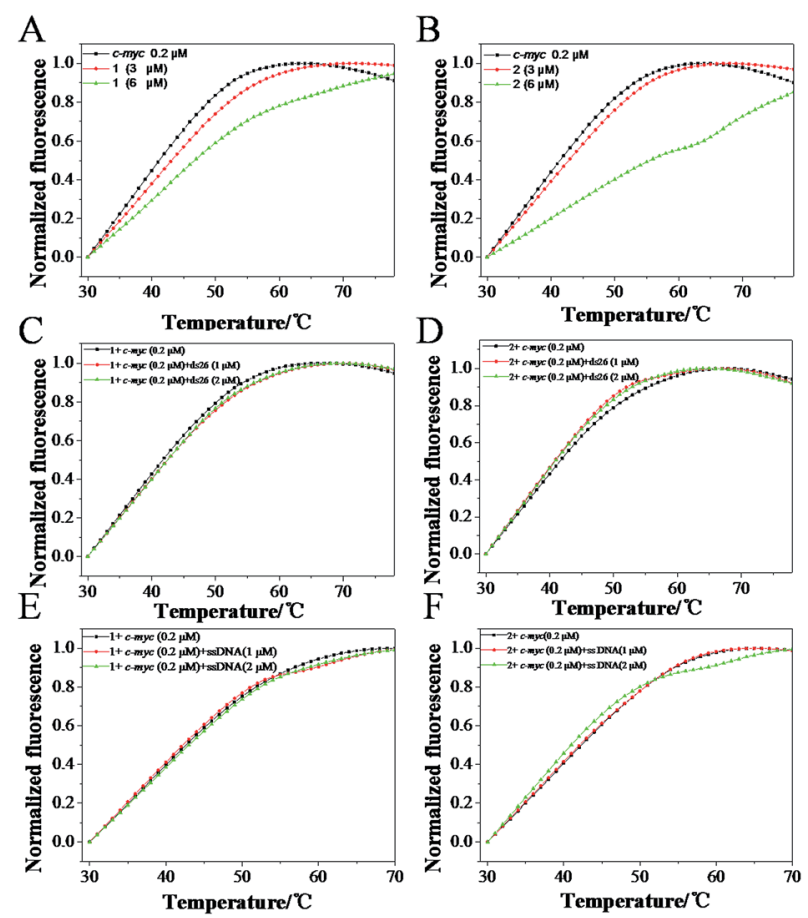

Fig. 7 FRET melting profiles of $c-m y c$ G4 DNA in the absence and in presence of 1 (A) and 2 (B) ([c-myc G4 DNA] $=0.2 \mu \mathrm{M})$ and the competition FRET-melting assay with ds 26 in the presence of $3 \mu \mathrm{M} 1$ (C) and 2 (D) and with ssDNA in the presence of $3 \mu \mathrm{M} 1$ (E) and 2 (F), $([R u]=3 \mu \mathrm{M},[c-m y c \mathrm{G} 4 \mathrm{DNA}]=0.2 \mu \mathrm{M})$. 
almost little obvious change in the presence of excess duplex ds26 DNA or ssDNA. When $\mathrm{r}([\mathrm{ds} 26] /[c-m y c])=10$, the $\Delta T_{\mathrm{m}}$ for 1 and 2 was about 0.86 and $-0.9{ }^{\circ} \mathrm{C}$ with a drop of less than $5 \%$, respectively (Fig. 7C and D). Moreover, with the excessive supplies of ssDNA, it was also observed that no remarkable change of $\Delta T_{\mathrm{m}}$ in the presence of 1 and 2 (Fig. 7E and F). The results indicated that this class of $\mathrm{Ru}(\mathrm{II})$ complexes could selectively bind to G-quadruplex DNA more strongly than to single or double-strand DNA, which could act as a switch-on luminescence probe to selective recognize $c$-myc G-quadruplex DNA. ${ }^{33-35}$

\section{Conclusions}

In conclusion, two ruthenium(II) complexes modified by aryl ethyl group, $\left[\mathrm{Ru}(\text { phen })_{2}(\mathrm{~L})\right]\left(\mathrm{ClO}_{4}\right)_{2}$ (L = TMSEPIP, 1; BEPIP, 2) were synthesized in this study using Sonogashira coupling reaction under microwave irradiation. It was confirmed that the luminescence of $\mathbf{1}$ decreased in the presence of $c$-myc Gquadruplex DNA, the luminescence of 2 increased obviously under the same conditions. It was interesting to find by AFM that 1 could promote $c$-myc G-quadruplex DNA self-assembly to form a nano-network structure, while 2 formed a nanowire structure. Further studies showed that $\mathbf{1}$ was inserted into the groove formed by base pairs A6-G8 and G21-T23 of c-myc Gquadruplex DNA, while 2 was inserted into the groove formed by G7-G9 and G22-A24. It is speculated that 2 can be developed as a potential luminescent switch-on probe through selectively recognizing and promoting self-assembly of $c$-myc G-quadruplex DNA.

\section{Acknowledgements}

This work was supported by the authors acknowledge the National Nature Science Foundation of China (81572926); the Provincial Major Scientific Research Projects in Universities of Guangdong Province (2014KZDXM053); the Science and Technology Project of Guangdong Province (2014A020212312); the Innovation Projects in Universities of Guangdong Province (2015cxqx151).

\section{Notes and references}

1 S. Lattmann, M. B. Stadler, J. P. Vaughn, S. A. Akman and Y. Nagamine, Nucleic Acids Res., 2011, 39, 9390-9404.

2 N. M. Hessari, L. Spindler, T. Troha, W. C. Lam, I. DrevenšekOlenik and M. W. Silva, Chem.-Eur. J., 2014, 20, 3626-3630.

3 L. A. Yatsunyk, O. Piétrement, D. Albrecht, P. L. Tran, D. Renčiuk, H. Sugiyama, J. M. Arbona, J. P. Aimé and J. L. Mergny, ACS Nano, 2013, 7, 5701-5710.

4 W. Li, Y. Yang, S. Jiang, H. Yan and Y. Liu, J. Am. Chem. Soc., 2014, 136, 729-734.

5 T. G. Edwardson, K. M. Carneiro, C. K. Mclaughlin, C. J. Serpell and H. F. Sleiman, Nat. Chem., 2013, 5, 868-875.

6 A. A. Almaqwashi, T. Paramanathan, I. Rouzina and M. C. Williams, Nucleic Acids Res., 2016, 44, 3971-3988.

7 L. Liu and H. Zhang, Biomaterials, 2010, 31, 1380-1391.
8 B. Yu, Y. Chen, C. Ouyang, H. Huang, L. Ji and H. Chao, Chem. Commun., 2013, 49, 810-812.

9 K. Qiu, B. Yu, H. Huang, P. Zhang, J. Huang, S. Zou, Y. Chen, L. Ji and H. Chao, Sci. Rep., 2014, 5, 10707.

10 X. Chen, J. H. Wu, Y. W. Lai, R. Zhao, H. Chao and L. N. Ji, Dalton Trans., 2013, 42, 4386-4397.

11 Q. Wu, T. Chen, Z. Zhang, S. Liao, X. Wu, J. Wu, W. Mei, Y. Chen, W. Wu and L. Zeng, Dalton Trans., 2014, 43, 9216-9225.

12 C. Zhao, L. Wu, J. Ren, Y. Xu and X. Qu, J. Am. Chem. Soc., 2013, 135, 18786-18789.

13 S. H. Chan, H. Yang, H. T. Kwan, Z. Cheng, P. Lee, L. P. Bai, Z. H. Jiang, C. Y. Wong, W. F. Fong and C. H. Leung, Biochemistry, 2011, 93, 1055-1064.

14 A. Ambrus, D. Chen, J. Dai, R. A. Jones and D. Yang, Biochemistry, 2005, 44, 2048-2058.

15 N. H. Damrauer, T. R. Boussie, A. Martin Devenney and J. K. Mccusker, J. Am. Chem. Soc., 1997, 119, 8253-8268.

16 B. Hetrick, M. S. Han, L. A. Helgeson and B. J. Nolen, Chem. Biol., 2013, 20, 701-712.

17 R. Kieltyka, P. Englebienne, J. Fakhoury, C. Autexier, N. Moitessier and H. F. Sleiman, J. Am. Chem. Soc., 2008, 130, 10040-10041.

18 D. B. Kitchen, H. Decornez, J. R. Furr and J. Bajorath, Nat. Rev. Drug Discovery, 2004, 3, 935-949.

19 Z. P. Zeng, Q. Wu, F. Y. Sun, K. D. Zheng and W. J. Mei, Inorg. Chem., 2016, 55, 5710-5718.

20 H. Qin, J. Ren, J. Wang and E. Wang, Chem. Commun., 2010, 46, 7385-7387.

21 M. H. W. Stopel, C. Blum and V. Subramaniam, J. Phys. Chem. Lett., 2014, 5, 3259-3264.

22 W. Liu, M. Lin, X. Yang, B. Wu, N. Chen, Q. Wang, K. Wang and S. Qin, Analyst, 2016, 141, 4463-4469.

23 B. Y. Man, D. S. Chan, H. Yang, S. W. Ang, F. Yang, S. C. Yan, C. M. Ho, P. Wu, C. M. Che, C. H. Leung and D. L. Ma, Chem. Commun., 2010, 46, 8534-8536.

24 L. Lu, D. S. H. Chan, D. W. J. Kwong, H. Z. He, C. H. Leung and D. L. Ma, Chem. Sci., 2014, 5, 4561-4568.

25 K. H. Leung, H. Z. He, B. He, H. J. Zhong, S. Lin, Y. T. Wang, D. L. Ma and C. H. Leung, Chem. Sci., 2015, 6, 2166-2171.

26 L. T. Costa, M. Kerkmann, G. Hartmann, S. Endres, P. M. Bisch, W. M. Heckl and S. Thalhammer, Biochem. Biophys. Res. Commun., 2004, 313, 1065-1072.

27 P. P. Neelakandan, Z. Pan, M. Hariharan, Y. Zheng, H. Weissman, B. Rybtchinski and F. D. Lewis, J. Am. Chem. Soc., 2010, 132, 15808-15813.

28 H. Wang, G. J. Nora, H. Ghodke and P. L. Opresko, J. Biol. Chem., 2011, 286, 7479-7489.

29 J. Walter, P. J. Sherwood, W. Lin, D. Segets, W. F. Stafford and W. Peukert, Anal. Chem., 2015, 87, 3396-3403.

30 P. Anzini, C. Xu, S. Hughes, E. Magnotti, T. Jiang, L. Hemmingsen, B. Demeler and V. P. Conticello, J. Am. Chem. Soc., 2013, 135, 10278-10281.

31 A. M. Chiorcea-Paquim, P. V. Santos, R. Eritja and A. M. Oliveira-Brett, Phys. Chem. Chem. Phys., 2013, 15, 9117-9124. 
32 A. K. Mårtensson and P. Lincoln, Dalton Trans., 2015, 44, 34 M. Sproviero, K. L. Fadock, A. A. Witham, R. A. Manderville, 3604-3613.

P. Sharma and S. D. Wetmore, Chem. Sci., 2013, 5, 778-796.

33 X. Chen, J. H. Wu, Y. W. Lai, R. Zhao, H. Chao and L. N. Ji, 35 S. Lin, B. He, C. Yang, C.-H. Leung, J.-L. Mergny and Dalton Trans., 2013, 42, 4386-4397. D.-L. Ma, Chem. Commun., 2015, 51, 16033-16036. 